\title{
TCF3/HLF Fusion Protein
}

National Cancer Institute

\section{Source}

National Cancer Institute. TCF3/HLF Fusion Protein. NCI Thesaurus. Code C99290.

A fusion protein ( $574 \mathrm{aa}, \sim 59 \mathrm{kDa}$ ) encoded by the TCF3/HLF fusion gene. This protein is comprised of the $\mathrm{N}$-terminal transactivation domains of the transcription factor E2-alpha protein fused to the C-terminal basic leucine zipper bZIP DNA binding and protein dimerization regions of the hepatic leukemia factor protein. 